DOI https://doi.org/10.18551/rjoas.2018-08.27

\title{
THE DESIGNATION AUTHORITY OF ACTIVE POLRI OFFICER AS ACTING GOVERNOR OF INDONESIA
}

\author{
Adp Diki Rinal \\ Post Graduate School, University of Airlangga, Indonesia \\ E-mail: nisasanur.na@gmail.com
}

\begin{abstract}
The objectives of this research: to analyze and explain the validity of the actions of the President of the Republic of Indonesia in appointing an Senior National Police Officer as Acting Official Governor; to analyze and explain the legal consequences of appointing an Senior National Police Officer as Acting Official Governor. The result of the research concludes that Presidential Decree on Appointment of Senior National Police Officer as Acting Official Governor based on Praesumptio iustae causa principle is valid as long as there is no cancellation; the legal consequences of the Presidential Decree shall be in accordance with the expiration of the term of office as stated in the Presidential Decree. Legal consequences related to the right of officers appointed as Acting Official Governor in accordance with applicable laws and regulations.
\end{abstract}

\section{KEY WORDS}

Acting Official Governor, legal consequences, normative legal research, Presidential Decree.

According to the law article 1 of President Regulation number 11 of 2015 about Home Affair Ministry (Later on will be referred as Perpres Kemendagri), it is stated that Ministry of Home Affairs is under control and responsible to Indonesian President, the ministry is now led by Tjahjo Kumolo. The duties of the ministry is stated on article 2 of Perpres Kemendagri which is implementing the internal affairs of the nation to help the president to run the country.

As the date of head regional election (Later on will be referred as Pilkada) is about near in 2019, there are will be some leaderless regions. Eventually, the president has a right to appoint a state officer to be an acting governor which has no leader on it. But, there are some systems of procedures that must be proceeded before by giving a mandate to the minister.

Moreover, this study would not only try to examine the designation procedure and legal consequence by appointing Polri (Indonesian Police Officer), it does also need to examine the policies regulation of Polri Designation as an acting governor. In the end, the decision of president to choose police officer as acting governor must not suffer both the society and Polri itself.

This study aims to to analyze and explain the validity of the actions of the President of the Republic of Indonesia in appointing senior police officer as acting governor. Then, the study will analyze the legal consequence of appointing senior police officer as acting governor.

\section{METHODS OF RESEARCH}

The normative type is applied in this research. According to Peter Mahmud Marzuki, Research on Law is a process of law regulation finding, or finding the law doctrine to reveal the current law issue faced by societies. Based on the background of study, there are some regulations that clash each other. The study is conducted to minimise the blur vision of police officer as an acting governor regulation towards the law. That is why, the research uses normative method to analyse the issue.

The primary source of data used in normative research consists of law materials which has normative regulation and related to the issue of study, they are as follow: 
The Primary Law Material. The primary law material which is in concerned with senior police officer as an acting governor appointment consists of, as follow:

- The Constitution of Republic of Indonesia 1945.

- Law number 23/Prp/1959 about emergency situation.

- Law number 28 of 1999 about The Implementation of Nation without corruption, collusion, and nepotism.

- Law number 2 of 2002 about Indonesian Police of Republic of Indonesia.

- Law number 12 of 2011 about the regulation of Constitution Establishment.

- Law number 39 of 2008 about State Ministry.

- Law number 5 of 2014 about Civil State Apparatus.

- Law number 17 of 2014 about People's Consultative Assembly, House of Representative, Regional Representative Board, Regional House of Representative.

- Law number 23 of 2014 about Regional Governance.

- Law number 9 of 2015 about amendment of Law number 23 of 2014 about Regional Governance.

- Law number 10 of 2016 about second amendment of Law number 1 of 2015 about Establishment of Government Regulation Replacement of Law number 1 of 2014 about Governor, Mayor, Regent Election.

- Law number 23 of 2011 about amendment of Law number 19 of 2010 about Governor's Duty Implementation, Authorities, and The Economic Status as Representation of Government in Regional Level.

- Presidential Regulation number 165 of 2014 about Kerja Cabinet.

- Presidential Regulation number 11 of 2015 about Ministry of Home Affairs.

- Presidential Regulation number 143/P/2016 about The Establishment of Respected Dismissal of West Sulawesi Governor and the Vice Governor 2011-2016 and Assignment of New Governor of West Sulawesi.

- Presidential Decision number 143/P/2016 about Validation of of Respected Dismissal of West Sulawesi Governor and the Vice Governor 2011-2016 and Assignment of New Governor of West Sulawesi.

- Ministry of Home Affair Decision number 121/430/SJ about Application of Acting Governor Candidates.

Secondary Law Material. It consists of law materials which support the explanation of primary Law material, it could be in a form of literature of journal and books which are related to the issue.

Tertiary Law Material. It consists of Law that gives clue and explanation of Primary and Secondary law material, for examples The Law Dictionary.

\section{RESULTS AND DISCUSSION}

The Legitimate Action of Indonesian President towards Polri Personnel Appointment as Acting Governor. According to law number 39 of 2008 about state ministry, The president of Indonesia, Ir. Joko Widodo, could establish the Kerja Cabinet. From the cabinet, another institutions are then established to help the government to run the country which is then referred as State Ministry. There is also President Decision number 165 of 2014 that become primary principles for the ministers to execute their duties and authorities.

Stated in President Decision article 1 point 1 number 165 of 2014, it states that the amounts of Kerja Ministers are 34 Ministries. In another law, article 15 of Ministry law states that the maximum amount of ministries, as previously stated in article 12, 13, and 14, are 34 people.

The purpose of Kerja cabinet establishment is ,stated in article 14 of Ministry Law, the synchronisation and coordination between ministries and president will be hold by Coordination Ministry. The duty of the ministries, as stated in article 7 of Ministry Law, are different within their unique business to help the president and government. Moreover, stated in article 12 of Ministry Law, it says: 
"The President shall establish the foreign, domestic and defence ministries, as defined in the 1945 Constitution of the State of the Republic of Indonesia".

It was explained in article 13 of Ministry Law that:

1. The presidents form the cabinet as stated in article 5 point (2) and (3);

2. The characteristics of Ministry establishment, as stated in point (1), must hold:

- Efficiency and Effectiveness;

- The Duties coverage and Proportion Burden;

- Continuity, Synchronisation, and Consolidate duties implementation and/or;

- The Global Social Development.

One of the ministry who responsible and has function to implement internal affairs is Home Affairs Ministry. In accordance with the law issue conducted in this study, the related ministry in Acting Governor appointment is The ministry of Home Affairs. The position of Home Affairs ministry, as stated in Kemendagri Law article 1, is as follow:

- The Ministry of Home Affairs is under control and responsible to the president;

- The ministry of Home Affairs is led by Minister.

Eventually, the ministers of home affairs which are the extension order of president possessed a right to appoint active police officer to act as an acting governor. Right now, the ministry of home affair is led by Tjahjo Kumolo. The duties of minister, as stated in article 2 of president decision, is implementing the internal national affairs to elp president and government to run the country.

As the legitimate action of president in appointing active personnel as acting governor, it is done by publishing the president decision letter. The letter has legal status and possessed law strength. It is then proceeded to instruct the chosen candidate to run the position after he or she have been inaugurated by the president.

As stated previously in background of study, the appointment of personnel to be acting governor must follow several procedures. According to Ida Nuraida, Procedures is series of phase or implementation whereas the job is done through what to do, how to do, why to do, where to do, and who to do. From the definition, we can conclude that the purpose of procedure is to make the job become easier.

The Legal Consequence of Polri Personnel Appointment as an Acting Governor. After discussing the legitimate actions of the President of the Republic of Indonesia in the appointment of POLRI's active officers and their legal consequences, then, the next discussion will be discussed on the position and role of acting Governor. In Indonesia, the Governor is domiciled as the regional head of a province. While the acting Governor himself has a role as an executor of regular duties of definitive officials, they are unable to remain as described in Article 83 of the Regional Government Law. The President of the Republic of Indonesia is represented by the Minister of Home Affairs entitled to appoint the Governor's Coordinator if there is a leadership vacuum in the position of the provincial head of the Province, namely the Governor. This is stipulated in Article 86 paragraph (2) of the Regional Government Law stating that if the governor is temporarily suspended and there is no deputy governor, the President of the Republic of Indonesia shall stipulate the Acting Governor upon the proposal of the Minister.

The condition of leaderless position of a province is caused by varies of events. Based on article 83 of regional governance law, there are several events that may result in leaderless condition of a region, as follow:

- The head or vice of a region is temporally dismissed without consideration from regional house of representative as a result of civil law violation that turns them into defendant must face minimum five years in jail. The action may consist of corruption, terrorism, treason, threaten national defence, and/or other action that may be a threat of country union.

- The head or vice head that become a defendant, as stated in article 1 , is temporally dismissed based on register of the court. 
- The dismissal of head or vice head of a region, as stated in article 1 and 2, are done by president for governor or the vice governor. The minister of home affairs may dismiss the mayor or vice mayor and regent or vice regent.

- The head or vice of a region is temporally dismissed without consideration from regional house of representative as a result of civil law violation that turns them into defendant, as stated in article 1, is according to firm decision of the courtyard.

- The dismissal, as stated in article 4, is done by president for governor or the vice governor. The minister of home affairs may dismiss the mayor or vice mayor and regent or vice regent.

The publishing of president decision is already accordance with specialist principles and also municipalities of good governance. There was no errors found nor law violation during the implementation of president decision number 143-P/2016. But, as an act of law, there must be law consequence as result of law event. As the act of law causes law event, instead, the act of law may result in law relation. Thus, the law consequence may be defined as a result of impact that come from action of law or relationship of law.

Pipin SYarif states his opinion about Law consequence, as follow

The consequences of law are all the consequences that occur from all legal acts committed by legal subjects to the object of law or other consequences caused by certain events by the law concerned has been determined or considered as a result of law.

Based on two definitions above, the consequence of law is an act that comes from law subject that may result in any condition that is caused by law event. In accordance with the background of this study, the consequence of law is the responsible of The president as the subject of law in this issue by publishing President Decision number 143/P/2016.

By following the legal presumption principles, it means that every decision of government is considered as legal and does not against the precious law, until there is a cancel on the corresponding decision, the presidents decision is considered as a legal letter. The law expert Sukardi argues about the cancellation of law as he says:

"In the legal system of Indonesia, there is no recognition of a null and void or van rechtswege nietig decision. The prevailing concept is irreversible (vernietigbaar). The underlying principle is the principle of presumption of legitimacy where in the library known as the principle of praesumptio iustae causa whose meaning is that every act of government is legal as long as has not been proven otherwise. With the use of praesumptio iustae causa principle, then the legal effect that occurs is ex nunc or since the cancellation. In practice (based on research) this has not been regulated".

Whereas, the concept of law cancellation form, according to Philipus M. Hadjon, he states:

- The illegal decision may cause "nietigheid van rechtswege"(Cancelled for the sake of Law), "nietig" (Cancel) atau "vernietigbaar" (cancellable).

- Niegtig means that action of law is considered as null or never occurred. The consequences may result in the deletion of the significant law.

- Vernietigbaar means that the consequence and the action of law is considered as exist until the cnacllation of law itsef by the judge or other competent state institution.

- Nietigheid van Rechtswege means that the existence of certain law is deleted without any further legal decision to cancel the action.

\section{CONCLUSION}

Based on the result of study about designation authority of active polri officer as acting governor by president of republic of Indonesia, the study found some conclusions as stated below:

According to the first discussion, it concludes that the presidential decision number $143 / P / 2016$ by the president of republic of Indonesia, it includes as authority discursion within action of law that may result in legal consequence. The publish of this decision is an action of legitimate law in appointing police officers to be an acting governor. Even though, 
there is a clash with the norms. But, from principles of praesumptio iustae causa, the decision is considered as legal until the cancellation of the law. The purpose of decision implementation is already in accordance with Nation of Law principle, it is proved that the decision is done without any cancellation appeal as result of authorities, procedures, or materials violation. Moreover, the establishment of the decision follows the general municipalities of good governance.

The law consequence of designation authority of active polri officer as acting governor by president of republic of Indonesia follows legal presumption principles. it means that every decision of government is considered as legal and does not against the precious law, until there is a cancel on the corresponding decision. Moreover, another principle says that there must not bee disadvantage for the chosen personnel in his future career. By choosing the active senior officer, it is expected to implement the clear and safe election party. The appointment of Polri personnel as acting governor is a gift and award from the government.

\section{SUGGESTIONS}

According to the conclusions above, there are several suggestions stated below:

In the implementation of law in a nation, every regulation must allow the government to do discursion. Because, the role and function of government that must actively serve society. The government is mandatory to provide the service to them. It is accordance with the constitution administration of government who already give the limitation through good governance principles.

For the enforcement of law, both Polri and president who became an acting governor, is suggested the Polri Law, about the right of personnel must be changed and follow the current situation of the state. Even though the constitution demands the president in serving his duty, but, the same condition must not be repeated in future within conventional law reason.

\section{REFERENCES}

1. Ganjong, 2007, Pemerintahan Daerah Kajian Politik dan Hukum, Bogor:Ghalia Indonesia. Hal.93.

2. Ida, Nuraida, 2008, Manajemen Administrasi Perkantoran, Yogyakarta: Kanisius. Hal.35

3. Ishaq, 2008, Dasar-Dasar IImu Hukum Cetakan I. Jakarta: Sinar Grafika. Hal. 86.

4. Kamus Besar Bahasa Indonesia (selanjutnya disebut KBBI), edisi IV, cetakan ke-19 September 2015. Hal. 554.

5. Peter Mahmud Marzuki, 2011, Penelitian Hukum, Jakarta: Kencana Pernada Media Grup. Hal.35.

6. Philipus M. Hadjon, 1985, Pengertian-pengertian Dasar Tentang Tindak Pemerintahan (Bestuurshandelingen), Surabaya: Percetakan Djumal. Hal. 24-25.

7. Pipin Syarifin, 2009, Pengantar Ilmu Hukum, Bandung: CV. Pustaka Setia. Hal.71.

8. Prajudi Atmosudirjo, 1981, Hukum Administrasi Negara, Jakarta: Ghalia Indonesia. Hal. 56.

9. Ridwan HR, 2014, Hukum Administrasi Negara (edisi revisi), Jakarta: PT Raja Grafindo Persada. Hal. 99. 